\title{
GREEN CONSTRUCTION IN BUILDING RENOVATION
}

\author{
Barbara KSIT $^{1}$, Michał MAJCHEREK ${ }^{2}$ \\ Poznan University of Technology, Poznań, Poland
}

\begin{abstract}
Modern materials and construction solutions draw more and more attention to ecology and building certification. Among the criteria appearing in revitalization, an important element is bringing plants back into heavily urbanized areas. In its natural form, this is not possible to carry out everywhere, often requiring large amounts of space. Nowadays, however, there are a number of green roofs and green wall systems, allowing "greener" construction without making significant changes in the urban environment.

The article includes a presentation and analysis of selected solutions of biological surfaces known as green roofs and green walls, specifying various solutions and their most important features. The case study focuses primarily on material and design solutions, as well as the potential benefits, risks and limitations in their use.

Plants structures on the surfaces of vertical and horizontal partitions continue to be a very interesting alternative to take into account when applying for grants, such as LEED or BREEAM certificates.
\end{abstract}

Keywords: green buildings, revitalization, green roofs, green walls, sustainable buildings.

\footnotetext{
${ }^{1}$ Corresponding author: Poznan University of Technology, Institute of Structural Engineering, 5 M. Skłodowskiej-Curie Sq., 60-965 Poznań, Poland, e-mail: barbara.ksit@put.poznan.pl, tel. +48616652864

${ }^{2}$ Corresponding author: Poznan University of Technology, Institute of Structural Engineering, 5 M. Skłodowskiej-Curie Sq., 60-965 Poznań, Poland, e-mail: michal.r.majcherek@doctorate.put.poznan.pl, tel. 533-257-758
} 


\section{REVITALIZATION OF URBANIZED AREAS}

The application of plants in construction in not an invention of the XXI century. The first notes on applying flora in architecture can be encountered as far back as the Ancient Times. Although the form in which they are used has changed over the centuries, plants continue to constitute an inseparable element of landscape architecture. Unfortunately, in many cases their improper location and uncontrolled growth can be the source of numerous problems connected with increased humidity and destruction of elevations and building constructions. Plants in the surroundings of a building are also positive examples of nature and construction cooperating with each other. An important parameter is, for example, the quality of the air we breathe every day. A particularly eloquent example here can be Cracow, where the permissible norms of harmful substances (gases and dusts) in the air are exceeded every year, going as far as to reach levels when the environment becomes toxic. Greenery may not be the ideal solution to this problem; however, it does make it possible to significantly reduce air pollution, mainly by slowing the process of evaporation, or through the production of oxygen. An additional argument in favor of designating areas of cities as a form of introducing greenery is the Act on environmental protection and development, Journal of Laws 00.48.550 from 14 June 2000.

City greenery is under protection. In accordance with the provisions of Article 42 and those further found in the Act of 31 January 1980 on environmental protection and development:

- when changing the development of a green area in the city for other purposes, laws regarding the development and passing of the local land use plan are applied,

- chemical substances can be used on streets, squares and public roads only in such a way that does not harm city greenery,

- earthworks carried out in green areas cannot damage trees.

However these laws, along with greenery protection zones in the developed land use plans for urban areas can later prove to be a major difficulty in various projects.

\section{GREEN ROOFS AND WALLS}

In current times, finding solutions which will make it possible to introduce greenery to heavily urbanized areas without the necessity of designating additional usable surface area for this purpose has become a significant ecological issue. Systems of green roofs (Fig. 1) turned out to be an answer to the above presented problem, followed a few years later by green walls. Over the last decade, many various solutions for green roofs and walls have been 
developed, both in terms of insulation layers as well as the actual construction. Ecological systems make it possible to take advantage of greenery while keeping it completely isolated from the building partitions.

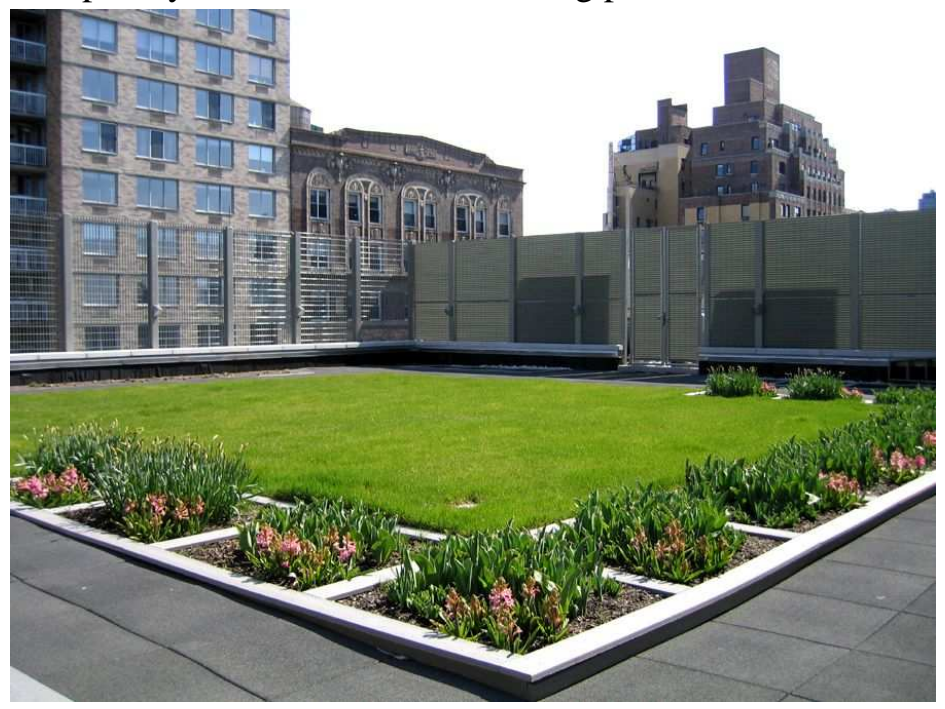

Fig. 1. Example of a green roof [7]

Green roofs work very well not only in terms of retaining water, but also as a buffer layer, allowing for the proper thermal regulation of the building. The dark surface of the roof covered by plants has additional insulation layers which heat up significantly less than commonly used roofing felt or membranes. It was even possible to solve the problem of aggressively expanding roots, which, at the beginning, posed a significant problem to such solutions. All of this has a very strong effect on the so-called phenomenon of "heat islands", the restriction of which continues to pose a significant challenge large metropolises (Fig. 2).

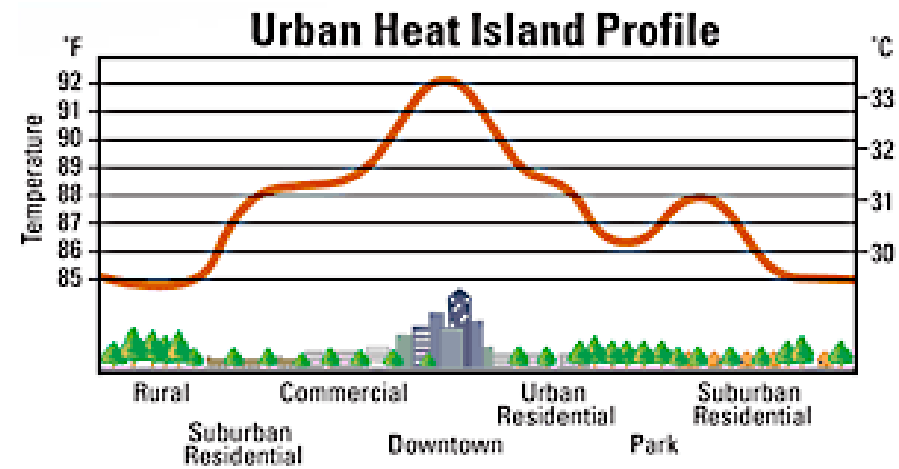

Fig. 2. Urban heat island [8] 
Along with the development of green roofs, making it possible to apply not only small plants but also lush shrubs or even trees, actions aimed at taking advantage of an even greater potential of surfaces other than building rooftops were initiated. It turned out that plants can also cover the elevations of buildings. The main assumption of vertical greenery systems was creating a partition which will not result in the degradation of the physical properties of vertical building partitions (Fig. 3). These solutions are currently becoming more and more popular, although they continue to differ from other solutions in terms of prices and do not posses separate legal regulations, which would make them possible to apply more freely.

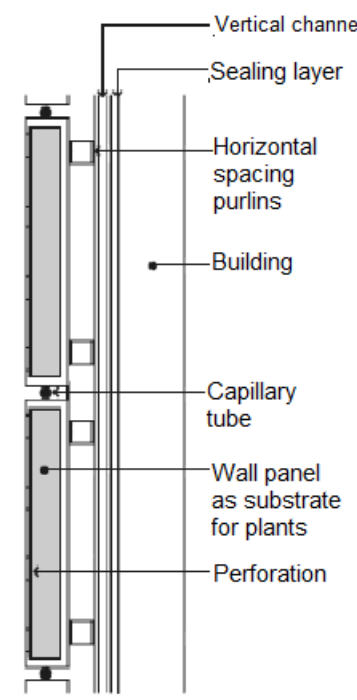

PANEL SYSTEM

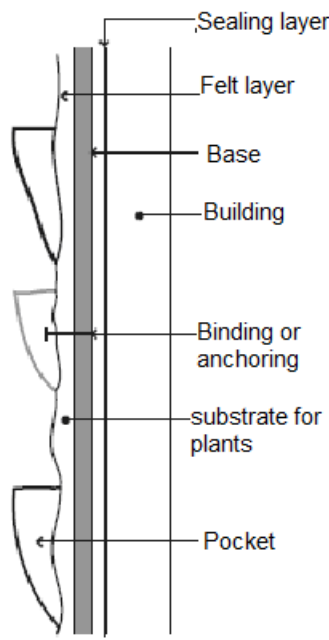

FELT SYSTEM

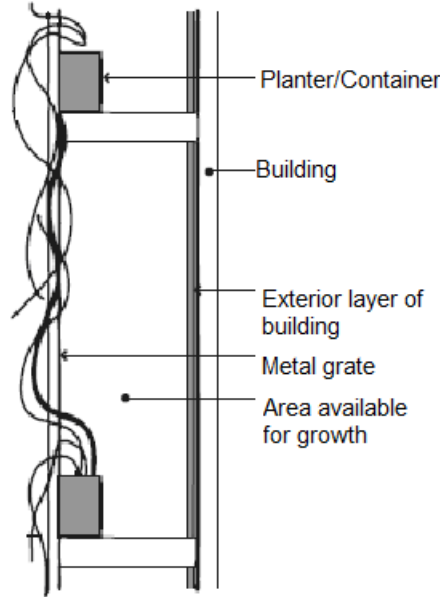

CONTAINER AND/OR GRATE SYSTEM

Fig. 3. Scheme of three different systems of green walls [5]

Green wall solutions are diverse enough and available worldwide that they can be successfully adapted to just about all kinds of construction, at the same time increasing the biologically active surface available to the building and its surroundings. These types of solutions do not require application on the entire surface of the elevation, but make it possible to apply partitions selectively, only in more attractive places. There are even examples of cases where greenery in the form of wall covering was formed into the logo of the company, thus becoming a "living advertisement" (Fig. 4). 


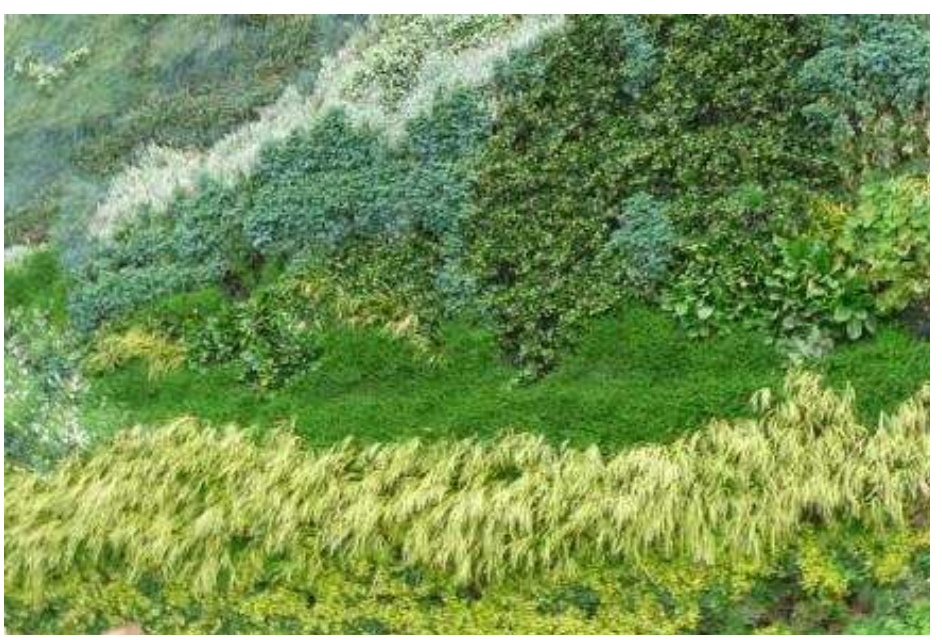

Fig. 4. Green wall as a Van Gogh painting - London

Despite their innovative nature and indisputable positive influence on people and the environment, many people remain skeptical in regards to the abovepresented solutions. This very often results from the lack of skills exhibited by the builder, or the lack of proper assessment at the planning stage, as there have been cases where water leakage or the premature death of plants took place. In many cases, the blame is placed on improper climate conditions. This argument, however, is unfounded, especially when taking into account that a significant part of the first green walls were created in Canada, an area with much harsher climate conditions.

It is also worth remembering that when making the decision to construct vertical garden walls, a complicated construction is not always necessary. With a proper approach to the problem (consultations with an architect and botanist), the simplest green wall constructions can be based on connectors in the form of mounting brackets connected to the surface of the building and a woven fencing mesh, commonly used as fencing (Fig. 5 and 6).

\section{GREEN PARITIONS IN LIGHT OF ECOLGOICAL CERTIFICATION}

As of today, in the era of sustainable construction, applying systems of green roofs as well as green partitions is becoming an unquestionable necessity. The first argument supporting such a thesis is most certainly the possibility of adding parts of the green roof surface to the required biologically active surface area present around the designed building, which must be specified in the project. Even disregarding the values in use of greenery on a roof, we also have 
the possibility of increasing the surface area of the building, thus also the usable area which, as it is known, is particularly important for potential investors.

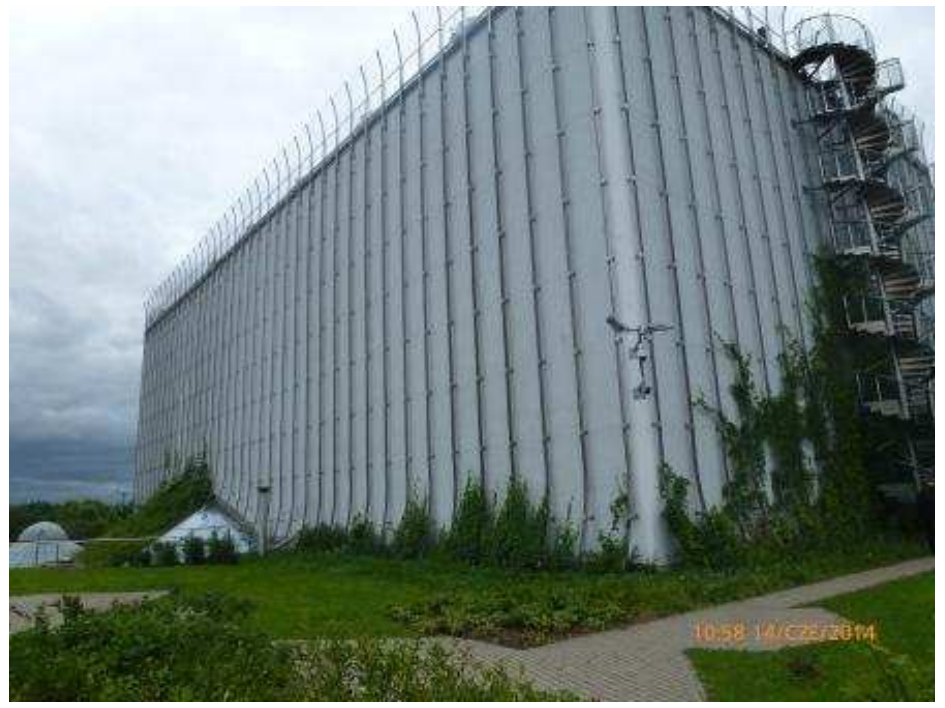

Fig. 5. Example of green wall - Philharmonic Hall in Białystok

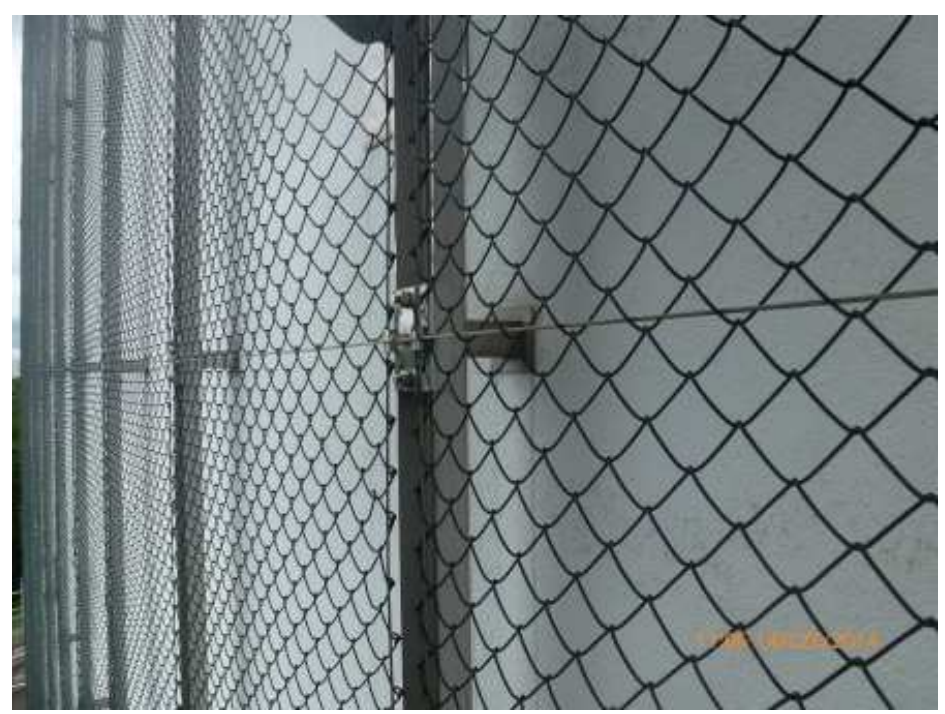

Fig. 6. Construction for green wall - Philharmonic Hall in Białystok

Changes in this respect are taking place not only in Poland. Also in systems of multi-criteria building evaluation, such as LEED or BREEAM, additional points can be gained, without which achieving the highest marks may prove to be 
much more difficult. Point categories in LEED, in terms of using biologically active surfaces, can pertain to, among others, the energy and water management of the building, utilization of locally available materials, or tackling the urban heat island effect.

Table 1. Green roofs and points in LEED classification [9]

\begin{tabular}{|l|c|}
\hline \multicolumn{1}{|c|}{ LEED category } & $\begin{array}{c}\text { Amount of } \\
\text { points possible } \\
\text { to obtain }\end{array}$ \\
\hline SS Credit 5.1 - Site Development - Protect or Restore Habitat & 1 pt. \\
\hline SS Credit 5.2 - Site Development - Maximize Open Space & 1 pt. \\
\hline SS Credit 6.1 - Storm Water Design: Quantity Control & 1 pt. \\
\hline SS Credit 7.2 - Heat Island Effect: Roof & 1 pt. \\
\hline WE Credit 1 -Water Efficient Landscaping & $2-4$ pts. \\
\hline EA Credit 1 - Optimize Energy Performance & up to 19 pts. \\
\hline MR Credit 3 - Material Reuse & $1-2$ pts. \\
\hline MR Credit 4 - Recycled Content & $1-2$ pts. \\
\hline MR Credit 5.1 - Regional Material & $1-2$ pts. \\
\hline
\end{tabular}

\section{CONCLUSIONS}

Ecological technology connected with the revitalization of elevations uses vast surfaces of existing buildings, putting the construction of the building under a small amount of stress in exchange for enriching the urban environment with biologically active areas. Living plants on a large wall surface act as a filter they retain dust, cleaning the air without damaging the surface layer of the wall. Ecological solutions also include lowering the temperature within the city - thus reducing the greenhouse effect, significantly lowering the amount of $\mathrm{CO}_{2}$ entering the atmosphere.

Moreover, thanks to the green covering, the building gains an addition protective surface, which in the summer lowers the temperature in the building and, in the winter, acts as an insulation layer. Thanks to such technology, it is possible to significantly reduce costs connected with upkeeping the existing objects, which can be an important argument for many investors assuming revitalization works to consider.

\section{REFERENCES}

1. B. Ksit, Systemy koordynujace projekty nowopowstajacych budynków jak $i$ poddawanych renowacjom $w$ kontekście ekologicznym, Konferencja Naukowo-Techniczna, Wałcz 2011. 
2. J. Marchwiński, K. Zielonko-Jung, Wspótczesna architektura proekologiczna, PWN, Warszawa 2012.

3. Ustawa o ochronie $i$ ksztattowaniu środowiska, Dz. U. $00.48 .550 \mathrm{z}$ dnia 14 czerwca 2000.

4. Green Wall Benefits - LEED Credits [http://greenovergrey.com/].

5. Beyond Green Roofs: 15 Vertically Vegetated Buildings, Portal WebEcoist [http://webecoist.momtastic.com/].

6. Zakaz wychodzenia na spacer, Angorka nr 49 - 4. grudnia 2011.

7. The International Greenroof \& Greenwall Projects Database, Portal internetowy [http://www.greenroofs.com/].

8. The Encyclopedia of Earth, Portal internetowy [http://www.eoearth.org].

9. Green Roof Technology, [http://www.greenrooftechnology.com].

\section{ZIELONE BUDOWNICTWO W RENOWACJI BUDYNKÓW}

\section{Streszczenie}

Współczesne rozwiązania materiałowe i konstrukcyjne kładą coraz większy nacisk na kwestię ekologii oraz certyfikacji budynków. Wśród aspektów powtarzających się jako kryteria widnieje rewitalizacja, której istotnym elementem jest wprowadzanie na powrót roślinności do silnie zurbanizowanych aglomeracji miejskich. Nie wszędzie jest to jednak możliwe w naturalnej formie, wymagającej niejednokrotnie znacznych przestrzeni. W związku z powyższym powstały i nadal powstają liczne systemu dachów zielonych oraz zielonych ścian, pozwalające ,zazielenić” budynek bez konieczności wprowadzania znaczących zmian w układzie zabudowy miejskiej i przeznaczania cennych powierzchni użytkowych.

Artykuł stanowi prezentację oraz analizę wybranych rozwiązań powierzchni biologicznie czynnych określanych mianem dachów zielonych i ścian zielonych, wskazując ich różnorodne rozwiązania oraz najważniejsze funkcje. Studium przypadków uwzględnia przede wszystkim rozwiązania materiałowe, rozwiązania konstrukcyjne, a także potencjalne korzyści, zagrożenia i ograniczenia podczas ich stosowania. Struktury roślin na powierzchniach przegród pionowych i poziomych, stanowią wciąż niezwykle interesującą alternatywę, uwzględnianą również przy ubieganiu się o uzyskanie takich certyfikatów jak LEED, czy BREEAM.

Słowa kluczowe: zielone budownictwo, rewitalizacja, dachy zielone, ściany zielone, budownictwo zrównoważone.

Editor received the manuscript: 22.01.2015 